\title{
INTRODUCTION
}

\section{The Hostis Generis Humani: A Challenge to International Law}

\author{
Luigi Corrias \& Wouter Veraart
}

\section{Introduction}

This special issue celebrates the work of David Luban. Besides the keynote article of Professor Luban, it contains comments by four renowned scholars and Luban's reply to them. ${ }^{1}$ Professor Luban's oeuvre largely covers two areas. On the one hand, he has written extensively on legal ethics. Recently, he has turned his attention to the use of torture by the U.S. Government and, specifically, to the role lawyers have played legitimizing this use. The other area in which professor Luban works is the philosophy of international criminal law. He has published highly influential articles on, among other topics, the concept of crimes against humanity and the legitimacy of international criminal law. ${ }^{2}$ His keynote article in this issue belongs to the second area. It addresses the question whether we ought to (re)introduce the notion of the enemy of humanity (hostis generis humani) within international criminal law.

\section{The challenge}

Ever since its introduction in the Nuremberg Trials the notion of crimes against humanity has provoked a discussion whether those guilty of this crime could be considered an enemy of all humanity. In her analysis of Adolf Eichmann, Hannah Arendt argued that he did constitute a hostis generis humani and this was a crucial argument in her defence of giving him the death penalty. Yet, this immediately poses international criminal law with a dilemma: how can someone who as an enemy falls outside of humanity still be considered within the protection of the law? With the help of Gustav Radbruch we may reformulate this dilemma as the tension between two core legal values. ${ }^{3}$ On the one hand, and Arendt seems to

1 Except for the reply, the texts were all presented at a seminar at the Vrije Universiteit Amsterdam in May 2018. This meeting was made possible thanks to the generous financial support of the Netherlands Association for Philosophy of Law (VWR) and the Kooijmans Institute for Law and Governance of the Vrije Universiteit Amsterdam. We also appreciate the comments of two anonymous reviewers. Gerben Geessink helped with the formatting of the footnotes to all the articles.

2 See in particular David Luban, 'A Theory of Crimes Against Humanity,' Yale Journal of International Law 29 (2004): 85-167.

3 Cf. Gustav Radbruch, 'Legal Philosophy,' in The Legal Philosophies of Lask, Radbruch, and Dabin, trans. Kurt Wilk (Cambridge, MA: Harvard University Press, 1950), 72-112. 
defend this view, doing justice to the suffering of the victims means punishing the criminals in a proportionate way. But what does retributive justice mean when the crimes committed are among the most heinous ones known? ${ }^{4}$ On the other hand, legal certainty demands that also the suspects of these crimes should be treated as everyone else and, therefore, ought to have a right to a fair trial, legal assistance by a qualified lawyer and access to an independent and impartial judge, among other things.

Note that this is in no way a theoretical debate only. What is at stake here is the question whether international criminal law is able to present itself credibly as something else than Siegerjustiz in the face of extreme injustice. Radbruch's third core value, legal expediency or the purposiveness of law, comes into play when we take into consideration that there is more than one possible way to deal with a violent past. ${ }^{5}$ Depending on the specific circumstances of the case, a legal criminal procedure may not be the best path to take if one wants to achieve peaceful coexistence of (former) oppressor and oppressed.

Renewed interest in the notion of the hostis generis humani seems to fit well within a larger development in international law where scholars have pointed to an increasing role of references to the concept of humanity. ${ }^{6}$ Some have greeted this development enthusiastically and have even gone so far as to speak of a new era in the history of international law where humanity replaces sovereignty. ${ }^{7}$ Others, however, have vehemently rejected this view as naive and point to the political origins of all references to humanity. ${ }^{8}$ The criticism of this latter group of scholars recalls one of the critiques formulated by Carl Schmitt. ${ }^{9}$ As is wellknown, Schmitt argues that the political manifests itself through the friendenemy distinction. ${ }^{10}$ He stresses that the enemy is a public enemy: hostis, not inimicus. An enemy may thus socially, economically and even ethically stand close to me. Indeed, Schmitt explicitly warns against branding an enemy an enemy of all humanity. For this would rob him or her of all protection. A political enemy is someone who I am willing to kill in war, if necessary. As a political enemy, that person is, however, equal to me. An enemy of all humanity falls outside of this

4 See, in a critical vein, Carlos Santiago Nino, Radical Evil on Trial (New Haven/London: Yale University Press, 1996), 138-48.

5 Wouter Veraart, 'Forgetting, Remembering, Forgiving, and the Mundane Legal Order,' in Public Forgiveness in Post-Conflict Contexts, eds. Bas van Stokkom, Neelke Doorn, and Paul van Tongeren (Cambridge/Antwerp/Portland: Intersentia, 2012), 65-89.

6 For an overview and references, see Britta van Beers, Luigi Corrias and Wouter G. Werner, eds., Humanity Across International Law and Biolaw (Cambridge: Cambridge University Press, 2014).

7 See, e.g., Ruti G. Teitel, Humanity's Law (Oxford: Oxford University Press, 2011) and Anne Peters, 'Humanity as the A and $\Omega$ of Sovereignty' European Journal of International Law 20 (2009): 513-44.

8 Martti Koskenniemi, 'Review of Humanity's Law by Ruti Teitel,' Ethics and International Affairs 26/3 (2012): 395-98.

9 Carl Schmitt, The Concept of the Political, trans. George Schwab (Chicago: The University of Chicago Press, 2007).

10 Theo de Wit, De onontkoombaarheid van de politiek. De soevereine vijand in de politieke filosofie van Carl Schmitt (Ubbergen: Pomppers, 1992). 
realm: he or she has become a moral enemy. In a war against such an enemy - the last war to end all wars - all means are allowed to eradicate him.

Schmitt's critique resonates, unexpectedly perhaps, with the analysis of Alain Finkielkraut of the Klaus Barbie trial. ${ }^{11}$ In a comment on Primo Levi, Finkielkraut argues how the Holocaust has shown that individual men and women are the guardians of humanity, for 'humanity itself can die. It is at the mercy of men, and most especially of those who consider themselves as its emissaries or as the executors of its great designs. The notion of a crime against humanity is the legal evidence of this realization. ${ }^{12}$ Central to any humane account of humanity is the institutionalization of conflict and thus "humanity ceases to be humane as soon as there is no longer a place for an "enemy" in the idea it holds of itself and its destiny. ${ }^{13}$

Historically, legal-political conceptions of humanity and 'the human' have always been ambiguous, and often highly controversial. They also have been instrumental to radically evil deeds. ${ }^{14}$ In the colonial era, reductionist racial and gendered conceptions of humanity and the human legal subject were central to the legal frameworks of colonial empires, enabling and legitimizing enslavement, large scale deprivations of property rights, and other crimes against peoples who were considered to be outside the scope of humanity or in any case less than human. ${ }^{15}$

The challenge that the hostis generis humani poses to international criminal law and to the philosophy of this field seems to be that even those who by committing crimes against humanity have transgressed the boundaries of the international legal order are to remain included in humanity. Is it possible to reintroduce the notion of an enemy of all humanity into our vocabulary - a notion which seems to emphasize the exclusion of the person to whom we give this title - while insisting upon including him as a human legal subject worthy of the protection of the law, at the very same time?

\section{The contributions}

In his keynote article David Luban explores the possibility of reintroducing the concept of a hostis generis humani in international criminal law. Taking a genealogical approach, he starts by tracing the notion back to Cicero's view on pirates. Luban argues how pirates were considered enemies of all humanity because they disrespected state authority as such. In modernity, the torturer has taken over

11 Thanks to Theo de Wit for pointing this out to us.

12 Alain Finkielkraut, Remembering in Vain: The Klaus Barbie Trial and Crimes against Humanity (New York: Columbia University Press, 1992), 31.

13 Finkielkraut, Remembering in Vain, 58.

14 See Alain Finkielkraut, In the Name of Humanity: Reflections on the Twentieth Century, revised edition (New York: Columbia University Press, 2000).

15 See Brenna Bhandar, Colonial Lives of Property: Law, Land and Racial Regimes of Ownership (Durham: Duke University Press, 2018). 
this role as enemy of all humanity. Yet, crucially, torturers got this title for their assaults on human rights. Luban then goes on to uncover an alternative genealogy: that of the tyrant. The crimes of tyrants and crimes against humanity both infringe upon what Luban calls 'our character as political animals.' The concept of a hostis generis humani is, Luban argues, crucial to explaining why international criminal law is both everyone's business and an acknowledgement of the existence of radical evil. As such, it comes with an understanding of humanity as a moral community which calls its enemies to account by way of a fair trial. Thus, the enemy of all humanity is both a jurisdictional and a substantive notion.

The response of Antony Duff takes issue with the jurisdictional line of Luban's article. Duff argues that understanding humanity as a moral community is not enough to grasp why 'we' may call an enemy of all humanity to account. Criminal law, Duff submits, always presupposes a political or civil order which is wronged by the crime. While crimes against humanity destroy domestic political communities, an international criminal process speaking with a 'universal,' moral voice fails to restore civil order at the domestic level. This problem also underlies the principle of subsidiarity: under which conditions could the moral voice of the International Criminal Court (ICC) replace the legal-political voice of domestic courts? The solution Duff sketches is to understand the political community underlying international criminal law as one composed of the political communities of states (not of individual human beings). The ICC may then claim jurisdiction for crimes against humanity, even though it will always remain a second-best option when compared to domestic, national courts.

Basing herself on a thorough study of the trial transcripts of a number of cases of international tribunals, Sofia Stolk questions whether we actually need the concept of a hostis generis humani. She shows that the term is not explicitly used in the case law, as Luban already noted. Stolk, while agreeing with Luban's contention that those who commit acts of radical evil are to remain part of humanity, goes on to argue that the notion of an enemy of all humanity is both too broad and too narrow. It is too broad since it amalgamates different understandings of humanity. It is too narrow for it fails to grasp the different kinds of evil perpetrated. Hence, Stolk concludes, the notion ought to be dismissed as inherently ambiguous and unnecessary.

In his contribution Marc de Wilde also dismisses the concept of a hostis generis humani because it has no added value. Moreover, he argues that the notion is a dangerous legal concept because it can be used and has effectively often been used to create parallel systems of justice: one for ordinary criminals, the other for enemies of all humanity. Whereas the first group could count on normal legal protection, the exceptional nature of the crimes committed by the second group implied that they were considered 'hors la loi': outside the pale of law and its ordinary protection. De Wilde traces an alternative genealogy to support this view. He also starts from Cicero but shows how he already broadens the scope of the notion of the hostis which he also uses to deprive inimical Roman citizens of legal protection. This rhetorical use of the concept, in a legal-political relevant way, 
may be traced throughout the history of European legal theory and practice, and culminates in the French Revolution, when, among countless others, Louis XVI was denounced as a hostis generis humani, and beheaded by guillotine on the Place de la Révolution. In a similar way, the Bush administration has used the notion to strip (alleged) terrorists of their right to a fair trial in Guantánamo Bay and elsewhere. It is this danger it poses to the rule of law that makes De Wilde reject the concept.

Louis Sicking takes a historical perspective to question the Ciceronian ancestry of the concept of a hostis generis humani in the figure of the pirate. Sicking shows that there is a competing understanding of piracy which is based on the writings of Augustine. According to the Augustinian paradigm, the notion of piracy was used to refer to enemy - as opposed to friendly, or authorized - action. The fact that robbery at sea was done by an enemy made it a criminal act, the act per se was not criminal. Furthermore, Sicking points out that it was the late medieval jurist Bartolus who is mainly responsible for what remains to be called the Ciceronian paradigm of piracy. Yet, piracy was the norm in medieval Europe and was only criminalized when sovereigns tried to establish themselves as effective rulers and took control over their territories. It is this political use of the concept of an enemy of all humanity that we ought to bear in mind when assessing analogies of piracy in the 21st century, Sicking argues.

This special issue ends with a 'reply to critics,' in which David Luban constructively and forcefully engages with the arguments of the four commentators. 